\title{
METODE MUHADDITSIN DI ERA MODERN ${ }^{1}$
}

\author{
Adriansyah \\ Universitas Islam Negeri Raden Fatah Palembang \\ adriansyahnz.1980@gmail.com
}

\begin{abstract}
After the era of tadwin, almost all disciplines of knowledge in the Islamic world, including the study of hadith, was considered "running on the spot." Yet, attention and maintenance of the hadith was still favored by intellectuals. Similarly, in the modern era, the hadith remains the object of criticism by not only Muslim intellectuals but also outsiders, such as the West. Western imperialism against the Islamic world in the past was now the beginning of the history of how Muslims are only able to "survive" rather than "attack." The emergence of defensive and reactive works against trends of the West in criticizing and blasphemed the hadith, then, such works became trends and supporting methodologies among Muslim observers of the hadith in today's modern era.
\end{abstract}

Keywords: Methods, muhadditsin, modern era, orientalist, specialist ra'y, and hadith scholars

\begin{abstract}
Abstrak
Pasca era tadwin, hampir seluruh disiplin ilmu di dunia Islam, termasuk kajian hadits, "berjalan di tempat". Sungguhpun demikian, perhatian dan pemeliharaan terhadap hadits masih tetap digemari oleh para intelektual. Begitu pula di era modern, hadits tetap menjadi objek kritik yang tidak hanya dilakukan oleh umat Islam sendiri, melainkan juga orangorang luar, seperti Barat. Imperialisme Barat terhadap dunia Islam di masa lampau hingga kini menjadi awal sejarah betapa umat Islam hanya mampu "bertahan" ketimbang "menyerang". Munculnya karya-karya pembelaan dan reaktif terhadap trend Barat dalam mengkritisi dan menghujat hadits, maka karya-karya tersebut menjadi trend dan metodologi lain yang dilakukan pemerhati hadits di era modern ini.
\end{abstract}

Kata Kunci: metode, muhadditsin, era modern, ahli ra'y, dan ahli hadits

\section{Pendahuluan}

Sebagai sumber hukum Islam, hadits memiliki peran signifikan dalam mengawal dan mengarahkan keberagamaan umat. Pentingnya hadits ini dilatarbelakangi oleh al-Qur'an yang menjadi pedoman utama umat Islam tidak secara mendetail memberikan jabarannya dalam mengawal perilaku keberagamaan umat. Oleh

\footnotetext{
${ }^{1}$ Dalam konteks tulisan ini, istilah "muhadditsin" penulis gunakan dalam arti yang sangat lentur, melampaui definisi yang diajukan para ulama hadits. Penulis lebih memahami istilah muhadditsin - dalam konteks pemahaman ini - sebagai "pengkaji dan pemerhati” hadits. Atas dasar inilah penulis memasukkan metode orientalis sebagai salah satu bahasannya.
} 
karena itu, eksistensi hadits menjadi hal yang penting untuk dijadikan rujukan lain dalam mengurai globalitas penjelasan al-Qur'an. Dalam konteks inilah hadits tidak saja berfungsi sebagai penegas pesan-pesan al-Qur'an (بيان تأكيد), tetapi juga berfungsi sebagai penjabar pesan-pesan alQur'an (بيان تفسير) dan pen-takhshish hal-hal yang umum atau pen-taqyid hal-hal yang mutlaq dari al-Qur'an. ${ }^{2}$

Begitu pentingnya posisi hadits dalam Islam, maka sahabat yang merupakan generasi pertama yang menemani Nabi berupaya menyelamatkan otentisitas dari segala upaya penyangkalannya. Beragam usaha dilakukan, misalnya menghafal, mencatat, dan menyebarkannya pada sahabatsahabat yang lain.

Pasca generasi sahabat, upaya serupa dilanjutkan oleh generasi tabi'in. Tentu saja cara pemeliharaannya tidak selalu sama dengan apa yang dilakukan oleh generasi sebelumnya. Begitu pula dengan generasi tabi' al-tabi'in dan seterusnya, upaya untuk terus mengamankan posisi hadits tetap dilakukan dengan beragam cara. Upaya tersebut tidak saja meriwayatkan hadits dari generasi ke generasi, tetapi juga mencatatnya dalam sebuah dokumen khusus, bahkan hingga dalam perkembangannya, hadits mengalami masa kegemilangan seiring terkodifikasi beberapa kumpulan hadits.

Tidak cukup sampai di situ, hadits yang secara massif terkodifikasi sekitar abad ke-3 H sebuah masa yang dalam kategorisasi sejarahwan muslim disebut era-tadwin - pun mulai mengidentifikasi sekaligus memilah antara hadits, qaul sahabat, dan fatwa-fatwa tabi'in, kemudian mensistematisasikan kumpulan hadits tersebut dalam bentuk musnad ${ }^{3}$ dan sistematisasi sesuai dengan problem-problem fiqh. Selain itu, seiring

\footnotetext{
${ }^{2}$ Muhammad 'Ajjaj al-Khatib, Ushul al-Hadits; Ulumuah wa Mushthalahahu (Beirut: Dar al-Fikr, 1989), 46-50. ${ }^{3}$ Lihat Abu Zahwu, al-Hadits wa al-Muhadditsun aw 'Inayat al-Ummah al-Islamiyah bi al-Sunnah alNabawiyah (Beirut: Dar al-Kitab al-'Arabi, 1984), 324.
}

dengan perdebatan yang sengit antara teolog dan ahlul hadits pada era itu, ulama berupaya membentengi sekaligus mengamankan hadits dari "polusi" yang memungkinkan tercemarnya validitas hadits. Munculnya kumpulan hadits yang popular dengan sebutan al-kutub al-sittah, musnad-musnad, dan karya-karya polemis sebagai respon terhadap kelompok teolog model Ibn Qutaibah menandai pola baru dalam menyusun hadits era ini. ${ }^{4}$

Walaupun waktu terus berlalu, namun perhatian ulama hadits dalam menyelamatkan salah satu sumber hukum Islam ini tidaklah berhenti. Dengan menggunakan cara-cara baru, atau sekedar memodifikasi model penyusunan yang dilakukan ulama sebelumnya, para pemerhati hadits abad ke-4 terus melakukan proyek besar penyelamatan hadits dengan caranya sendiri, seperti penyusunan karya yang berlabel shahih - semisal Shahih Ibn Khuzaimah dan Shahih Ibn Hibban, Sunan - semisal Sunan Daruquthni, Mustadrak semisal Mustadrak alHakim atau Mustakhrajat.

Pada era selanjutnya di mana muncul karyakarya syarah terhadap sejumlah kumpulan hadits yang terkodifikasi pada era sebelumnya. Selain karya syarah, karya-karya suntingan atas sejumlah kitab-kitab hadits atau ilmu hadits banyak dijumpai pada pasca abad ke-4 ini. Di samping itu, ada tren lain semisal men-takhrij hadits-hadits dari kitab-kitab - baik fiqh, tauhid, tasawuf - yang tidak menyebutkan sumber rujukannya. Kitabkitab semisal صaب الراية لأحاديث البداية karya Ibn Hajar al-Asqalani, لكافي الشاف في تخريج أحاديث الكشاديث البداف karya alHafiz Zain al-Din 'Abdurrahman ibn Husein al'Iraqi dan lain sebagainya.

Singkatnya, apa yang terjadi para era belakangan dalam hal pembenahan metodologis tidak lebih sebagai pengulangan dari apa yang dilakukan oleh generasi-generasi awal. Upayaupaya mereka hanyalah memodifikasi metodologis

${ }^{4}$ Ibid., 363. 
dari apa yang dilakukan ulama masa lalu.

Uraian berikut hendak membuktikan bahwa pasca era tadwin, hampir seluruh disiplin ilmu di dunia Islam, termasuk kajian hadits, "berjalan di tempat". Sungguhpun demikian, perhatian dan pemeliharaan terhadap hadits masih tetap digemari oleh para intelektual. Begitu pula di era modern, hadits tetap menjadi objek kritik yang tidak hanya dilakukan oleh umat Islam sendiri, melainkan juga orang-orang luar, seperti Barat. Imperialisme Barat terhadap dunia Islam di masa lampau hingga kini menjadi awal sejarah betapa umat Islam hanya mampu "bertahan" ketimbang “menyerang”. Munculnya karya-karya pembelaan dan reaktif terhadap trend Barat dalam mengkritisi dan menghujat hadits, maka karya-karya tersebut menjadi trend dan metodologi lain yang dilakukan pemerhati hadits di era modern ini.

Munculnya tokoh di era modern ini, semisal Mushtafa al-Siba'i, Muhammad Mushtafa al'Azmi dari kalangan mayoritas ahli hadits sebagai pembela hadits dari serangan kelompok Barat. Dalam hal ini orientalis, yang diwakili oleh Ignaz Goldzhiher dan Joseph Schacht, menyangsikan keberadaan hadits Nabi SAW, di lain pihak ada kelompok yang mulai menyangsikan kredibilitas hadits, bahkan sebagian yang lain menafikan peran hadits sebagai sumber hukum Islam. Menurut mereka, al-Qur'an telah memberikan penjelasan yang memadai apa yang dibutuhkan umat Islam. Kelompok ini lazim disebut ahli ra'yi yang diwakili oleh Ahmad Amin, Qasim Ahmad, dan Muhammad al-Ghazali. Di samping kelompok ahli ra'yi, muncul tokoh moderat dalam mengimbangi pemikiran ahli ra'yi yang memberi dampak tidak baik bagi dunia Islam, dalam hal ini di wakili Yusuf al-Qaradhawi.

Tokoh-tokoh hadits yang disebutkan di atas, memberikan warna baru dalam perkembangan pemikiran hadits di era modern. Tulisan ini disajikan untuk memberikan gambaran tentang metode muhadditsin di era modern dalam upaya menilai posisi dan peran hadits bagi umat Islam sebagai tradisi keilmuan keislaman.

\section{Potret Umum Dunia Muslim Abad Modern}

Pada abad ke-18, bangkitnya Barat sebagai kekuatan baru, Islam mengalami keterpurukan. Konsolidasi internal Islam yang tidak berhasil diwujudkan ditambah dengan bangkitnya Barat sebagai kekuatan pengganti menjadikan Islam benar-benar terpuruk. Sejak saat itulah Barat melakukan kolonisasi terhadap dunia muslim. Inggris misalnya pada abad ke-18 memasuki bekas kerajaan besar Islam, Moghul di India. Begitu pula Perancis yang dipimpin Napoleon Bonaparte berhasil menduduki Mesir. Kemudian pada era selanjutnya, kekuatan Eropa menjajah negara-negara muslim. Perancis menduduki Aljazair pada tahun 1830, Tunisia pada tahun 1881, Mesir pada tahun 1882, Sudan pada tahun 1889, Libya dan Maroko pada tahun 1921.

Seiring dengan ancaman Barat terhadap dunia muslim, di awal abad ke-19, ${ }^{5}$ teriak kebangkitan menggema di seluruh belahan dunia Arab. Fenomena apa yang disebut Arkoun dengan ledakan modernitas ${ }^{6}$ ini ditandai oleh kesadaran diri dunia Arab atas kelemahannya vis a vis Barat yang telah mengalami kebangkitan material dan intelektual.

Saat kritis yang sedemikian kompleks yang terjadi saat itu, dunia Arab mulai menyadari

\footnotetext{
${ }^{5}$ Hassan Hanafi melukiskan gambaran perkembangan dunia Arab pada tiga periode. Periode Pertama (Abad ke1 sampai abad ke-7 M). Pada periode ini, Islam mengalami kejayaannya yang kerap dikenal dengan zaman keemasan Islam. Periode kedua (abad ke-8 sampai abad ke-14 M).Pada periode ini, sejarah Islam mengalami kemunduran, dan periode ketiga (abad ke-15 sampai abad ke-21 M). Sejarah kebangkitan Islam yang kedua. Lihat Hassan Hanafi, al-Harakah al-Islamiyah al-Mu'ashirah Marhalatun Tarikhiyah Tsalitsah dan Abid al-Jabiri, Hiwar al-Masyriq wa al-Maghrib (Kairo: Madbuli, 1990), 34.

${ }^{6}$ Ledakan modernitas yang dimaksud adalah kekerasan suatu intervensi yang pada awalnya bersifat militer, lalu kegalauan susunan sebagai akibat pendampingan sebuah sektor penjajah dan sektor tradisional di dalam berbagai masyarakat yang ditaklukkan. Lihat M. Arkoun, Nalar Islami Nalar Modern; Berbagai Tantangan dan Jalan Baru, terj. Rahayu S. Hidayat, ), cet. I (Jakarta: INIS, 1994), 270. Cf. M. Arkoun, Pemikiran Arab ,terj. Yudian W. Asmin, cet. I (Yogyakarta: Pustaka Pelajar, 1996), 105.
} 
kelemahan dirinya dengan melakukan kritik diri (auto critique) atas kekurangannya. Krirtik diri yang tanpa henti menyadarkan ulama untuk memainkan peran utama mengkoordinasikan perjuangan melawan kekuasaan kolonial, yang akhirnya melahirkan kemenangan negara terjajah (dunia Arab). ${ }^{7}$ Faktor internal dan eksternal di atas, memberikan inspirasi pada munculnya kebangkitan dunia Arab. Menyikapi kondisi demikian, respons dan jawaban yang diberikan tidaklah seragam; mulai dari penolakan dan konfrontasi hingga kekaguman dan peniruan yang naïf. ${ }^{8}$ Kondisi keterbelahan mentalitas yang mendera umat Islam ini juga berdampak pada respons intelektual yang dinamis sekaligus beragam. Begitu pula dalam respons umat Islam dalam penyelamatan hadits.

Uraian berikut menjelaskan bagaimana respons umat Islam dalam upaya pemeliharaan hadits di tengah beragam arus intelektual yang dinamis dan beragam itu. Oleh karena itu, tulisan ini juga hendak memotret setidaknya empat metode pengkaji dan pemerhati hadits dalam upaya menilai posisi dan peran hadits bagi umat Islam.

\section{Kegiatan Pemeliharaan Hadits Pada Era Modern}

Krisis politik yang terjadi di dunia Muslim pasca runtuhnya Baghdad di tangan Tartar menyisakan beban psikologis yang luar biasa bagi umat Islam. Gagalnya konsolidasi internal umat Islam yang berujung pada lumpuhnya Islam menghadapi Barat menjadikan dunia Arab, pusat kelahiran Islam sebagai wilayah terjajah. Hampir di semua wilayah Arab, Barat berhasil menancapkan kekuasaannya melalui apa yang

\footnotetext{
${ }^{7}$ Abu Bakar A. Bagader, “Contemporary Islamic Movement in the Arab World", dalam Akbar S. Ahmed dan Hastings Donnan (ed), Islam, Globalization and Postmodernity (New York: Routledge: 1994), 115.

${ }^{8}$ John L. Esposito, Ancaman Islam; Mitos dan Realitas, terj. Alwiyah Abdurrahman dan MISSI (Bandung: Mizan, 1996), 62.
}

disebut imperialisme. Kedatangan Barat di dunia Islam tampak menjadi ancaman. Satu persatu negara Islam dikuasai oleh Barat dan sejak itulah dominasi Barat secara perlahan tapi pasti mempengaruhi cara berpikir umat Islam. Apa yang disebut modernisasi di dunia Islam menunjukkan betapa Barat yang mengaku dirinya modern seolah berhasil menuntut kesadaran umat Islam untuk modernisasi dirinya sehingga tidak menjadi negara terjajah. Mentalitas terjajah ini tentu saja berdampak pada aktifitas intelektual di dunia Islam, tidak terkecuali menyangkut pemeliharaan hadits.

Dalam realitas sosial, politik, dan ekonomi semacam itu, gairah untuk senantiasa memelihara salah satu sumber hukum Islam ini tetap saja dilakukan. Sebagaimana diketahui bahwa pasca terkodifikasinya sejumlah kitab-kitab induk dalam hadits pada abad ke- $3 \mathrm{H}$, aktivitas yang dilakukan oleh generasi pasca era tadwin itu adalah sistematisasi, penjabaran melalui karyakarya bermodel syarah, peng-indeks-an misalnya melalui penyusunan berdasarkan potongan awal (athraf) hadits, penyusunan mu'jam dan semacamnya. Begitu juga yang dilakukan oleh generasi selanjutnya hingga saat ini. Di samping melanjutkan kerja pemeliharaan hadits sebagaimana dilakukan oleh para pendahulunya, seperti men-syarah kitab-kitab induk dalam hadits, mensistematisasi penulisan hadits, pemberian anotasi terhadap literatur-literatur hadits klasik (tahqiq) dan semacamnya, ada upaya lain yang dilakukan oleh generasi saat ini. Satu hal yang sangat penting adalah "komputerisasi hadits". Sebenarnya, proyek komputerisasi hadits ini lebih pada merupakan respon atas pesatnya teknologi yang dipastikan juga terjadi di negaranegara Islam ketimbang penyempurnaan metode dalam penyusunan kitab-kitab hadits.

Di samping adanya upaya pemeliharaan dan penyelamatan terhadap hadits yang dilakukan ulama pada era modern ini, ada sebagian yang lain mulai menyangsikan kredibilitas hadits. Bahkan sebagian yang lain menafikan peran 
hadits sebagai sumber hukum Islam. Artinya, di samping pemeliharaan dan pembelaan yang luar biasa terhadap hadits, ada sebagian yang lain yang meragukan kegunaan hadits.

Makki al-Syami menjelaskan setidaknya ada enam pola yang dilakukan kelompok guna melemahkan atau bahkan mengingkari hadits. ${ }^{9}$ Pertama, pola pengingkaran (أسلوب الإنكار), misalnya dengan mengingkari kehujjahan hadits secara mutlak, mengingkari Sunnah atas dasar tidak adanya dalil yang tegas menyangkut persoalan ini, menolak penggunaan hadits ahad sebagai hujjah, menolak penggunaan hadits sebagai argumentasi dalam kaidah nahw dan sharaf.

Kedua, "pola selektif yang disengaja" dalam arti memilih dan memilah atas dasar kesadaran bahwa pada dasarnya dua hal atau lebih itu tidak perlu dipilah-pilah. Adakalanya pola ini berbentuk pemilihan dengan mempertimbangkan problem pertentangan antara akal dan naql, pemilihan berdasarkan preferensi bahwa nafsu atas teks dan pemilihan atas dasar penyesuaian agama dengan ilmu pengetahuan.

Ketiga, pola penyimpangan (أسلوب التحريف), seperti penyimpangan dengan mengganti lafazlafaz, penyimpangan dengan menambah lafaz hadits dan penyimpangan dengan mengurangi lafaz.

Keempat, pola interpretasi dan menyesatkan (أسلوب التأويل الباطل). Kelima, pola pemalsuan hadits (سلوب الوضع). Dan keenam, pola stigmatik (أسلوب التجريح). Keenam pola inilah yang mewarnai 'penyimpangan' dalam pemeliharaan hadits di era modern, baik itu yang dilakukan oleh orientalis maupun ahli ra’y di kalangan umat Islam.

\section{Metode Muhadditsin Era Modern}

Setidaknya ada empat metode yang diajukan "muhadditsin" (pengkaji dan pemerhati hadits),

${ }^{9}$ Makki Sami, al-Sunnah al-Nabawiyah wa Matha'in alMubtadi'ah Fiy Ha (Oman: Dar 'Ammr, 1999), 74. yaitu metode orientalis, metode ahli ra'y, metode mayoritas ahli hadits, dan metode moderat. Empat metode ini akan diuraikan secara terperinci dengan mengurai secara singkat tokoh yang mewakili metode-metode tersebut. Untuk metode orientalis, penulis hendak mengajukan Ignaz Goldzhiher dan Joseph Schacht sebagai sampel. Untuk metode ahli ra'y, penulis akan mengajukan tokoh-tokoh semisal Ahmad Amin, Qasim Ahmad, dan Muhammad al-Ghazali, untuk metode mayoritas ahli hadits akan dimunculkan tokoh semisal Mushthafa al-Siba'i dan Mushthafa 'Azami, sedangkan dari tokoh moderat, akan diusulkan nama Yusuf Qaradhawi.

\section{A. Metode Orientalis}

Tidak ada yang bisa memastikan sejak kapan Barat berminat mengkaji Islam, tapi yang jelas persentuhan pertama Barat dengan Islam adalah pada abad ke-8 sampai abad ke-9 $\mathrm{H}$ pasca terjadinya perang Mu'tah dan perang Tabuk. Pada saat itulah terjadi kontak pertama antara Islam dan Romawi. Dalam perjalanannya, terutama pasca terjadinya perang salib, pertemuan dalam arti konfrontasi antara Islam dan Barat yang akhirnya berujung pada kekalahan Islam, kontak IslamBarat kian intensif. Bahkan dengan kekalahan Islam, Barat dengan leluasa mengendalikan Islam. Era apa yang disebut imperialisme dan kolonialisme yang menjadikan tidak hanya fisik yang dijajah, tetapi juga pemikiran. Sejak saat itulah kajian-kajian Islam mulai diminati oleh Barat, termasuk juga kajian tentang hadits.

Dalam konteks kajian hadits, Mushthafa 'Azami menganggap Ignaz Goldziher-lah tokoh orientalis yang pertama kali melakukan kajian kritis terhadap hadits. ${ }^{10}$ Muhammedanische Studien, buku yang terbit di penghujung abad ke19, adalah buku pertama yang mencoba menyuguhkan argumentasi bahwa apa yang

\footnotetext{
${ }^{10}$ Mushthafa 'Azami, Hadits Nabawi dan Sejarah Kodifikasinya (Jakarta: Pustaka Firdaus), 3.
} 
disebut hadits diragukan otentisitasnya sebagai sabda Nabi. Menurut Goldziher, penelitian hadits yang dilakukan oleh ulama klasik tidak dapat dipertanggungjawabkan secara ilmiah karena kelemahan metodenya. Dengan mengajukan, pentingnya kritik matan, Goldziher menampik upaya ulama klasik yang hanya bersikukuh dengan kritik sanad sebagai metode penelitiannya. ${ }^{11}$ Argumentasi ini kian mendapat penajaman melalui karya Joseph Schacht yang berjudul The Origins of Muhammadan Jurisprudence.

Joseph Schacht mengawali penelitiannya tentang hadits melalui penelitian perkembangan hukum Islam. Ini penting dilakukan karena, menurut Schacht, perkembangan hukum Islam berkaitan erat dengan hadits dalam segenap tahap perkembangannya. Menurut Schacht, mazhabmazhab fiqh ini melahirkan pihak oposisi dengan semangat keagamaan yang dengan keliru menghasilkan informasi terperinci mengenai Nabi agar dapat dijadikan sebagai sumber otoritas pandangan-pandangannya dalam bidang hukum. Apa yang disebut dengan teori Projecting Back ${ }^{12}$ ini merupakan salah satu kata kunci Schacht dalam mengkritik otentisitas hadits.

Dalam mengkritisi matan hadits, Schacht melakukannya dengan cara mengambil beberapa contoh hadits yang terdapat dalam Kitab alMaghazi karya Musa ibn Uqbah al-Asadi ${ }^{13}$. Schacht mengutip dan menganalisa pernyataan Musa sebagai penulis kitab al-Maghazi bahwa ia

\footnotetext{
${ }^{11}$ Ibid.

${ }^{12}$ Menurut Schacht, hadits Nabi itu diciptakan oleh mazhab Irak sekitar abad ke-2 H. Sunnah Nabi, bagi Schacht hanyalah sekedar tradisi yang hidup dari mazhab tersebut yang dinyatakan berasal dari Nabi. Artinya, para ulama abad ke-2 $\mathrm{H}$ memproyeksikan teori-teori dan keputusan mereka ke belakang sampai pada mulut Nabi untuk menambahkan otoritas kepada teori-teori dan keputusankeputusan tersebut. Inilah yang ia sebut dengan teori projecting back. Lihat: M.M. 'Azami, Menguji Keaslian Hadits-hadits Hukum; Sanggahan atas The Origins of Muhammadan Jurisprudence Joseph Schacht (Jakarta: Pustaka Firdaus, 2004), 146.

${ }^{13}$ Al-'Azami, Hadits Nabawi dan Sejarah Kodifikasinya, 157.
}

hanya mengambil hadits-hadits yang bersumber dari al-Zuhri. Akan tetapi pada kenyataannya di dalam kitab tersebut terdapat beberapa riwayat yang tidak bersumber dari al-Zuhri seperti hadits nomor $8,9,10$, dan 12 . Selanjutnya untuk beberapa riwayat ini Schacht menganggapnya sebagai riwayat tambahan bukan berasal dari Nabi. Pada hadits nomor 9 yang menjelaskan bahwa Rasul tidak mengistimewakan Fatimah di mata hukum menurut Schacht merupakan hadits lemah. Kelemahan hadits yang pertama ialah karena tidak berasal dari al-Zuhri, ditambah lagi disebabkan oleh kandungan matan bertentangan dengan logika. Mustahil bagi Schacht tidak ada keistimewaan terhadap keluarga Rasul termasuk dalam bidang hukum.

Dengan demikian, kalau Goldziher meragukan hadits karena metode kritik matan tidak difungsikan, Schacht jauh melompat ke depan dalam hal penolakannya bahwa hadits bukanlah sabda Nabi. Singkatnya, orientalis yang diwakili oleh Goldziher dan Schacht ini tidak saja membantah otentisitas hadits, melainkan hendak melemahkan keyakinan umat Islam akan pentingnya hadits.

\section{B. Metode Ahli Ra'y}

Sebagai sebuah identitas, ahli ra'y sebagai lawan dari ahli hadits di masa lampau masih berkembang hingga saat ini. Istilah ahli ra'y digunakan bagi seseorang atau kelompok yang lebih menonjolkan akal daripada naql. Pertimbangan akal ini pula yang dijadikan argumentasi kalangan rasionalis ini untuk mengesampingkan hadits sebagai salah satu sumber pokok ajaran Islam.

Tentu saja penulis tidak hendak menggeneralisasi bahwa kalangan rasionalis lebih hendak mengesampingkan hadits daripada keyakinan umat Islam ketimbang merawat hadits. Tetapi penulis hendak mengatakan bahwa kecenderungan menyoal hadits ini dominan di kalangan rasionalis, walaupun mungkin cara 
inilah yang mereka tempuh dalam memelihara kelestarian hadits - sebuah cara yang dinilai keliru oleh kalangan ulama hadits. Berikut ini akan disuguhkan beberapa contoh 'pemeliharaan hadits' ala kelompok rasionalis di era modern, serta keberatan kelompok lain atas klaim pemeliharaan hadits mereka. Penulis hendak menyebut tiga tokoh yang mewakili kelompok rasionalis perihal bagaimana mereka menyikapi hadits Nabi. Mereka itu adalah Ahmad Amin, Qasim Ahmad dan Muhammad al-Ghazali. ${ }^{14}$

Ahmad Amin seorang putra Cairo yang lahir pada tanggal 1 Oktober $1886 \mathrm{M}$ menulis dalam bukunya Fajr al-Islam ${ }^{15}$ memberikan porsi penjelasan tentang hadits dalam bab khusus kurang lebih tujuh belas halaman. Ahmad Amin tampaknya sepakat dalam beberapa hal dengan apa yang juga didakwakan kalangan orientalis bahwa lamanya rentang kodifikasi hadits menjadi lahan empuk bagi kemungkinan terjadinya pemalsuan hadits. Bahkan ia meyakini bahwa pemalsuan hadits pada dasarnya telah terjadi pada masa Nabi dengan berdalih pada hadits yang diriwayatkan secara mutawatir berikut ini:

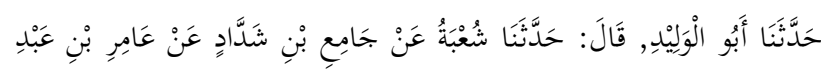

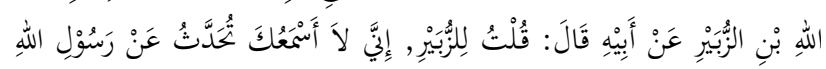

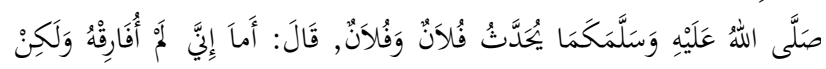

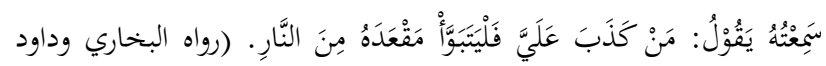

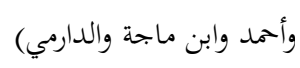

Massifnya pemalsuan hadits, jelas Ahmad Amin adalah akibat massifnya konversi agama yang dilakukan orang-orang Arab pada masa itu, di samping faktor fanatisme kelompok yang menonjolkan kelompoknya. Selain itu, Ahmad Amin menyayangkan dominasi kritik sanad dalam penentuan kualitas hadits, sementara kritik matan nyaris diabaikan. ${ }^{16}$ Hal lain yang menjadi sentrum

\footnotetext{
${ }^{14}$ Sebenarnya Abu Rayyah juga dimasukkan dalam kelompok ini, namun penulis hanya membatasi pada tokoh di atas.

${ }^{15}$ Ahmad Amin, Fajr al-Islam (t.tp: t.p., 1975), 208-234.

${ }^{16}$ Ibid.
}

pemikirannya dalam bidang hadits adalah penolakannya pada para kritikus hadits yang menganggap adil seluruh sahabat. Padahal menurutnya bahwa pada masanya sahabat itu mengkritisi kredibilitasnya masing-masing dan satu sahabat bisa saja menolak hadits yang diterima sahabat yang lain. Logika bahwa sahabat sepenuhnya adil ini tampaknya berat diterima oleh Ahmad Amin, mengingat disiplin yang secara khusus menilai pribadi perawi, ilmu al-jarh wa al-ta'dil, sebenarnya tidak lepas dari bias konflik kepentingan. ${ }^{17}$

Penilaian kritis Amin terhadap hadits ini sebenarnya tidak hendak menolak hadits sebagai sumber hukum Islam. Ia sadar betul akan pentingnya hadits dalam menjabarkan pesanpesan al-Qur'an. ${ }^{18}$ Hanya saja ia hendak memberikan penegasan sekaligus melengkapi upaya ulama hadits di masa lampau betapa pentingnya kritik matan - di samping kritik sanad - dalam menilai kualitas hadits. Penegasan akan pentingnya kritik matan ini bisa jadi menjadi strategi dia dalam memelihara otentisitas hadits. ${ }^{19}$

Mengikuti pemilahan Makki al-Syami mengenai strategi kelompok tertentu dalam menolak hadits sebagaimana dijabarkan di atas, maka Ahmad Amin tampaknya menggunakan "pola stigmatik", pola pengingkaran dan pola pemalsuan hadits sebagai medium kritiknya terhadap hadits.

Tokoh lain yang juga kritis terhadap hadits adalah Qasim Ahmad. Dalam bukunya yang diterjemahkan ke dalam Bahasa Arab, "I'adatu Taqyim al-Hadits: al- 'Audah ila al-Qur'an". Qasim Ahmad mengajukan keberatannya tentang posisi hadits sebagai sumber hukum Islam. Setidaknya ada empat hal yang hendak ia bantah

\footnotetext{
${ }^{17}$ Ibid., 216-217.

${ }^{18}$ Ia mengatakan: للحديث قيمة كبرى في الدين تلى رتبة القرأن. Ibid., 208.

${ }^{19}$ Mushtafa al-Syiba'i memberikan porsi khusus atas keberatannya terhadap komentar-komentar Ahmad Amin. Lihat: Mushtafa al-Syiba'i, al-Sunnah wa Makanatuha fi al-Tasyri'al-Islamiy (Beirut: Maktabah al-Islamiy, 1985), 236-290.
} 
menyangkut hadits. Pertama, bahwa hadits adalah wahyu layaknya al-Qur'an. Menurut Qasim tak ada satupun ayat al-Qur'an yang membenarkan pendapat tersebut..$^{20}$ Kedua, ia hendak menolak argumentasi ahli hadits yang mengatakan bahwa Rasulullah merupakan otoritas independen yang patut ditaati di samping kewajiban taat kepada Allah serta wujud ketaatan kepada Rasulullah adalah menerapkan hadits. Ia menolaknya dengan argumen bahwa tidak ada satupun ayat yang menjelaskan pemisahan otoritas Tuhan dan Rasul. Sedangkan argumentasi bahwa ketaatan kepada Allah mewujud dalam penerapan hadits sama sekali tidak benar karena diyakini bahwa apa yang dilakukan Nabi sebenarnya bersumber dari alQur'an. ${ }^{21}$

Hal ketiga adalah penolakan terhadap argumentasi ahli hadits yang mengatakan bahwa hadits merupakan alat tafsir al-Qur'an. Bagi Qasim Ahmad memahami al-Qur'an tidak memerlukan hadits, karena al-Qur'an secara tegas menjelaskan hal-hal agama yang terkait dengan ibadah, termasuk shalat. Ibadah shalat, menurut Qasim telah dijelaskan kepada Nabi Ibrahim dan kemudian diikuti oleh nabi-nabi setelahnya. Menyangkut shalat ini, tambah Qasim, hadits pun tidak memberikan perincian tentang tata laksananya. Kecuali shalat itu dilakukan berdasarkan pelajaran yang diperoleh secara turun temurun di mana Nabi Ibrahim sebagai sumber pertamanya. $^{22}$

Hal keempat adalah argumen ahli hadits tentang keharusan mengikuti Nabi yang didasarkan pada ayat berikut:

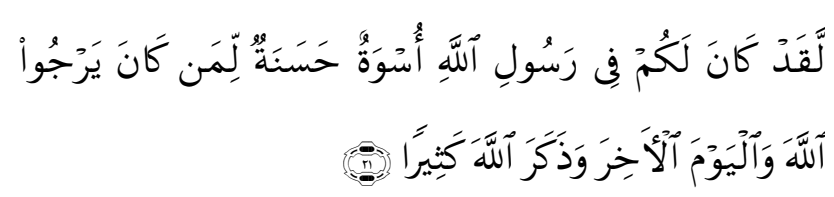

${ }^{20}$ Qasim Ahmad, I'adatu Taqyim al-Hadits: al- 'Audah ila al-Qur'an (Cairo: Madbuli al-Saghir, 1996), 75.

${ }^{21}$ Ibid., $78-81$.

${ }^{22}$ Ibid., 81-83.
Menurut Qasim, ayat ini terkait dengan peristiwa perang Ahzab yang mereka menduga bahwa Islam telah hilang. Oleh karena itu, memahami ayat ini lepas dari konteks khususnya pasti keliru. Kepatuhan kepada Nabi hanyalah sejauh terkait dengan keimanan kepada Allah dan komitmen penuh atas pesan-pesan al-Qur'an. Uswah hasanah dalam konteks ayat di atas, kata Qasim lebih terkait dengan tuntunan Nabi untuk beriman kepada Allah bukan pada tindakan pribadinya.

Keempat hal inilah yang menjadi fokus bukunya yang tampaknya hendak mengesampingkan posisi dan peran hadits. Qasim Ahmad hendak mengatakan bahwa al-Qur'an saja sudah cukup untuk dijadikan pedoman dalam beragama. Dalam konteks klasifikasi Makki alSyami di atas, Qasim dikategorikan sebagai orang yang menggunakan 'pola pengingkaran' terhadap hadits secara total.

Tokoh lainnya adalah Muhammad alGhazali. Melalui buku polemisnya, al-Sunnah alNabawiyah: Bayna Ahl al-Figh wa al-Hadits. ${ }^{23}$ Ghazali hendak mempertemukan upaya yang dilakukan ahli fiqih dan ahli hadits yang memiliki komitmen yang sama dalam memelihara otentisitas hadits. Dalam buku ini, Ghazali hendak memberikan posisi yang istimewa pada al-Qur'an, sehingga standar kualitas hadits harus diukur sejauh mana hadits itu tidak bertentangan dengan makna tekstual al-Qur'an. Di samping al-Qur'an, Ghazali menilai bahwa akal memiliki ruang istimewa dalam mengukur keshahihan hadits.

Sayangnya, upaya membela hadits yang dilakukan Ghazali ditanggapi minor oleh sejumlah kalangan. Bahkan tidak sedikit yang menuduhnya sebagai orang yang mengingkari Sunnah. Tuduhan itu bias jadi benar, walaupun tidak sepenuhnya. Memang Ghazali menolak sebagian hadits, tetapi tetap meyakini betapa pentingnya hadits bagi umat Islam. Meskipun

${ }^{23}$ Diterbitkan oleh penerbit Dar al-Syuruq, Kairo, 1989. 
tidak berprestasi melakukan kajian khusus untuk membuktikan otentisitas hadits, Ghazali sebenarnya hendak membela hadits melalui pemberian interpretasi-interpretasi yang sesuai. Upaya pemberian interpretasi inilah yang disalahpahami oleh kelompok yang tidak menyetujuinya. Bisa jadi, kelompok penantangnya akan menganggap Ghazali sebagai orang yang hendak merusak hadits melalui interpretasi yang menyesatkan, sebagaimana dalam klasifikasi Makki al-Syami.

Demikianlah gambaran pola pemeliharaan hadits atau bahkan pengingkaran hadits yang dilakukan oleh ketiga tokoh yang mewakili kelompok rasionalis.

\section{Metode Ahli Hadits}

Berbeda dengan Ahli Ra'y dan Orientalis, ahli hadits memiliki metode tersendiri dalam pembelaannya terhadap hadits. Ahli hadits era modern ini lebih menyibukkan diri dalam meluruskan pandangan-pandangan miring menyangkut hadits, ketimbang mengajukan metode yang unik. Dua tokoh yang hendak diangkat dalam tulisan ini menjadi contoh betapa ahli hadits lebih berada pada 'posisi defensif' menghadapi kuatnya arus yang mulai menyangsikan hadits sebagaimana dilakukan orientalis dan kelompok rasionalis dari kalangan umat Islam sendiri.

Mushthafa al-Syiba'i misalnya melalui bukunya al-Sunnah wa Makanatuha fiy Tasyri' al-Islamiy berupaya meluruskan pandanganpandangan minor terhadap hadits, baik yang dilakukan umat Islam sendiri maupun yang dilakukan orientalis. Al-Syiba'i mengawali uraian bukunya dengan menjelaskan posisi hadits dalam legislasi Islam yang kemudian dilanjutkan dengan pembahasan tentang apa yang dimaksud dengan Sunnah dan Hadits dan bagaimana ulama terdahulu menyelamatkan hadits. Selanjutnya ia menjelaskan problem pemalsuan hadits serta faktor-faktor yang memicu terjadinya pemalsuan hadits tersebut yang kemudian dilengkapi dengan bagaimana kegigihan ulama dalam menyikapi problem pemalsuan hadits.

Pada jabaran selanjutnya, al-Syiba'i menjelaskan akar-akar munculnya keraguan terhadap hadits dalam rentang waktu tertentu. Misalnya, bagaimana Syi'ah, Mu'tazilah, dan Mutakallimin memposisikan hadits. Selanjutnya ia menjelaskan fenomena pengingkaran pada hadits pada masa lampau dan masa kini. Dalam konteks ini, al-Syiba'i mengkaji bagaimana upaya orientalis merusak keyakinan umat Islam melalui informasi yang keliru tentang hadits. Ia juga mengkaji kekeliruan Ahmad Amin memahami hadits. Buku ini juga dilengkapi dengan penjelasan tentang posisi Sunnah di samping alQur'an serta penjelasan tentang imam mazhab yang empat serta menyusun al-Kutub al-Sittah.

Dari perincian isi buku itu, tampak bahwa Mushthafa al-Syiba'i hendak meyakinkan umat Islam betapa pentingnya posisi hadits bagi umat Islam, sekaligus pada saat yang sama mewaspadai segala upaya yang dilakukan baik orientalis atau kalangan umat Islam sendiri dalam menolak hadits secara perlahan-lahan.

Begitu juga apa yang dilakukan M.M. Azami. Dalam bukunya, Dirasat fiy al-Hadits alNabawi dan On Schacht's Origins of Muhammadan Jurisprudence, ${ }^{24}$ 'Azami mencoba meneguhkan pandangan ahli hadits masa lalu sekaligus pada saat yang sama menyerang tindakan orientalis yang dianggapnya serampangan dalam menilai hadits. Dalam buku yang pertama itu, 'Azami melakukan upaya yang nyaris mirip dengan apa yang dilakukan Mushthafa al-Syiba'i yang menjelaskan kedudukan Sunnah dalam Islam, penjelasan tentang orang-orang yang mengingkari hadits pada zaman dulu dan sekarang, aktivitas pencatatan hadits yang dilakukan sejak zaman

\footnotetext{
${ }^{24} \mathrm{Buku}$ ini telah diterjemahkan ke dalam Bahasa Indonesia oleh Ali Mushtafa Ya'qub dengan judul, Hadits Nabawi dan Sejarah Kodifikasinya (Jakarta: Pustaka Firdaus, 1994).
} 
Nabi, bagaimana hadits disebarkan, penjelasan tentang kitab-kitab hadits serta penjelasan tentang otentisitas hadits sebagaimana yang diragukan oleh kalangan orientalis. Sementara dalam bukunya yang kedua, 'Azami secara khusus mengkaji buku Joseph Schacht yang dianggap sebagai "kitab suci kedua" setelah karya Ignaz Goldziher oleh para orientalis.

Gambaran isi buku di atas menunjukkan bahwa 'Azami hendak mengkritisi sesat pikiran orientalis atau orang yang bermazhab dengan mereka dengan memberikan pembelaan yang luar biasa pada hadits sebagaimana dilakukan oleh para ulama mutaqaddimin .

Lagi-lagi, baik al-Syiba'i maupun 'Azami hanya berusaha membela hadits secara defensif. Namun demikian, kehadiran karya-karya, baik karya al-Syiba'i maupun 'Azami memberikan keteguhan tekad bagi kelompok pembela hadits untuk terus merawat dan menyelamatkan hadits Nabi dari rongrongan orang dalam dan luar sekaligus.

\section{Metode Moderat}

Metode terakhir adalah metode kelompok moderat. Penulis cenderung untuk menyebut Yusuf al-Qaradhawi sebagai tokoh yang mewakili kelompok ini. Melalui bukunya Kayfa Nata'ammal Ma'a al-Sunnah al-Nabawiyah (Ma'alim wa Dhawabith) - tampaknya buku ini merupakan bagian dari buku al-Madkhal liy Dirasatiy al-Sunnah al-Nabawiyah - Qaradhawi mengawali pembahasannya tentang "posisi dan kedudukan serta cara berinteraksi dengan Sunnah". Bab ini menjelaskan apa itu Sunnah dan bagaimana kedudukannya dalam Islam, apa yang harus dilakukan orang Islam terhadap Sunnah dan pengenalan pada prinsip dasar dalam berinteraksi dengan Sunnah. Menurutnya, setidaknya ada empat prinsip yang mesti dipedomani oleh orang yang hendak berinteraksi dengan Sunnah. Pertama, Sunnah hendaknya dijadikan patokan dalam tasyri' dan dakwah. Dalam konteks ini, alQaradhawi tidak hendak memilah antara ahli hadits dan ahli fiqih sebagaimana kecenderungan sebagian orang Mutaakhkhirin. Kedua, menolak hadits shahih sama halnya dengan menerima hadits palsu. Ketiga, menolak hadits shahih akibat kekeliruan dalam memahami. Keempat, cepatcepat menolak hadits shahih yang sulit dipahami adalah tindakan ngawur. Keempat hal inilah yang menjadi prinsip dasar dalam berinteraksi dengan Sunnah.

Dalam bab selanjutnya, Yusuf al-Qaradhawi menjelaskan posisi Sunnah sebagai sumber fiqih dan dakwah. Dalam bab ini, ia menjelaskan keniscayaan mempertautkan hadits dan fiqh, bukan malah memilahnya dalam posisi yang berseberangan. Di samping itu, ia juga menjelaskan bagaimana seharusnya juru dakwah memanfaatkan dalil-dalil hadits dalam materi dakwahnya, sekaligus pada saat yang sama, seorang juru dakwah idealnya harus memiliki kualitas dan kuantitas keilmuan yang memadai. Dalam konteks ini, Yusuf al-Qaradhawi memberikan aksentuasi pada problem hadits dha'if dan kemungkinan untuk dijadikan argumen.

Bab selanjutnya yang tampak menjadi inti buku ini adalah penjelasan tentang rambu-rambu umum yang mutlak diperhatikan dan dipedomani dalam berinteraksi dengan Sunnah. Dalam konteks ini, ada delapan petunjuk yang patut diperhatikan dalam berkomunikasi dengan hadits. Pertama, memahami Sunnah seharusnya sesuai dengan petunjuk al-Qur'an. Kedua, memadukan sejumlah hadits yang tercakup dalam satu tema besar. Ketiga, memadukan atau men-tarjih haditshadits yang seolah-olah bertentangan. Keempat, memahami hadits dengan mempertimbangkan latar belakang situasi dan kondisinya tatkala hadits itu diucapkan dan sekaligus bisa mencermati tujuannya. Kelima, perlunya memilah antara instrumen yang berubah-ubah dan sasaran yang konstan. Keenam, perlunya membedakan antara ungkapan yang bermakna sebenarnya (hakiki) dan bermakna metaforis (majazi) dalam memahami hadits. Ketujuh, membedakan antara 
alam ghaib dan alam kasat mata. Dan kedelapan, memastikan makna dan konotasi lafal-lafal hadits.

Dari kandungan isi buku itu, penulis melihat bahwa meskipun al-Qaradhawi menyangsikan sejumlah hadits yang bertolak belakang dengan akal, namun ia tidak tergesa-gesa menyimpulkan status hadits itu sebagaimana dilakukan Muhammad Ghazali. Ia meskipun kritis, relatif lebih berhati-hati dalam menyikapi dan memahami hadits Nabi.

\section{Kesimpulan}

Dari penjelasan di atas, dapat disimpulkan bahwa upaya pemeliharaan hadits terus senantiasa dilakukan. Memang upaya yang dilakukan antar generasi tidak selalu sama, dan itu tergantung pada kebutuhan masanya. Kalau pada abad ke-3 H, kodifikasi hadits dianggap mencapai puncaknya, maka generasi selanjutnya - di samping juga mengkodifikasi hadits-hadits yang masih tercecer - juga merancang pola sistematisasi yang lebih mencerminkan kebutuhan masanya. Misalnya, upaya pemberian komentar atas buku-buku induk atau penyusunan indeks hadits dan semacamnya. Begitu pula pada era modern ini, era yang ditandai dengan meningkatnya kemajuan teknologi direspon secara positif oleh pemerhati hadits. Terbentuknya software-software hadits menjadi bukti kreasi era kini dalam merawat kelangsungan kajian hadits.

Di samping upaya-upaya kreatif semacam itu, era modern ini juga ditandai oleh maraknya kajian yang berujung pada 'penyingkiran' otoritas hadits sebagai sumber hukum Islam. Apa yang dilakukan oleh orientalis menjadi salah satu contoh upaya melepas ketergantungan umat Islam dengan hadits. Upaya orientalis ini direspons secara beragam oleh umat Islam. Sebagian meresponsnya secara positif dalam arti mengapresiasi secara taken for granted, atau menerima secara selektif dan ada pula yang secara apriori menolaknya. Munculnya karya-karya reaktif dan affirmatif terhadap upaya yang dilancarkan orientalis ini menyemaraki gairah kajian hadits di era modern ini. Hadirnya tokohtokoh semisal Ahmad Amin, Abu Rayyah, Qasim Ahmad, Fazlurrahman, M.M. 'Azami, Nuruddin Itr, 'Ajjaj al-Khatib, Muhammad Ghazali, Yusuf al-Qaradhawi, Nashiruddin al-Albani, dan semacamnya menunjukkan semaraknya kajiankajian hadits, betapapun beragam orientasi yang digagasnya. Semua itu merupakan upaya untuk mengabdi kepada agama, walaupun cara pengabdiannya diutarakan secara beragam. Di sinilah letak kebijaksanaan kita dalam menyikapi perbedaan.

\section{Daftar Kepustakaan}

Ahmad, Qasim. I'adatu Taqyim al-Hadits: al'Audah ila al-Qur'an. Cairo: Madbuli alSaghir, 1996.

Ahmed, Akbar S. dan Hastings Donnan (Ed). Islam, Globalization and Postmodernity. New York: Routledge, 1994.

Amin, Ahmad. Fajr al-Islam. T.tp: t.p., 1975.

Arkoun, Muhammaed. Nalar Islami, Nalar Modern: Berbagai Tantangan dan Jalan Baru. Terj. Rahayu S. Hidayat. Jakarta: INIS, 1994.

Arkoun, Muhammed. Pemikiran Arab. Terj. Yudian W. Asmin. Yogyakarta: Pustaka Pelajar, 1996.

Azami, Muhammad Mushthafa. Hadits Nabawi dan Sejarah Kodifikasinya. Jakarta: Pustaka Firdaus, 1994.

Azami, Muhammad Mushthafa. Menguji Keaslian Hadits-hadits Hukum; Sanggahan atas The Origins of Muhammadan Jurisprudence Joseph Schacht. Jakarta: Pustaka Firdaus, 2004.

Esposito, John L. Ancaman Islam: Mitos dan realitas. Bandung: Mizan, 1996. 
Hanafi, Hassan dan Abid al-Jabiri. Hiwar al-Masyriq wa al-Maghrib. Cairo: Madbuli, 1990.

al-Khatib, Muhammad 'Ajjaj. Ushul al-Hadits: Ulumuha wa Mushthalahuhu. Beirut: Dar al-Fikr, 1989.

Makki, Syami. Al-Sunnah al-Nabawiyah wa Matha 'in al-Mubtadi'ah Fiha. Oman: Dar 'Ammr, 1999.
al-Syiba'i, Mushthafa. Al-Sunnah wa Makanatuha fi al-Tasyri' al-Islamiy. Beirut: Maktabah al-Islamiy, 1985.

Zahwu, Abu. Al-Hadits wa al-Muhadditsun aw Inayat al-Ummah al-Islamiyah biy alSunnah al-Nabawiyah. Beirut: Dar al-Fikr al-'Arabi, 1984. 